\title{
Trade-off between blue and grey water footprint of crop production at different nitrogen application rates under various field management practices
}

\author{
Abebe D. Chukalla ${ }^{\mathrm{a}, *}$, Maarten S. Krol ${ }^{\mathrm{a}}$, Arjen Y. Hoekstra ${ }^{\mathrm{a}, \mathrm{b}}$ \\ a Twente Water Centre, University of Twente, PO Box 217, 7500 AE Enschede, The Netherlands \\ ${ }^{\mathrm{b}}$ Institute of Water Policy, Lee Kuan Yew School of Public Policy, National University of Singapore, Singapore
}

\section{H I G H L I G H T S}

- Trade-off between water consumption and pollution in crop production is quantified.

- Blue and grey WF are minimum, and crop yield is maximum at different $\mathrm{N}$ rates.

- The economical optimal nitrogen rate varies if cost of water pollution is included.
G R A P H I C A L A B S T R A C T

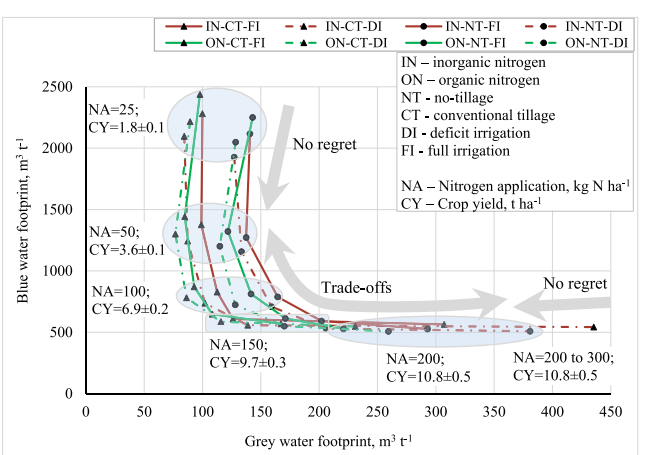

\section{A B S T R A C T}

In irrigated crop production, nitrogen $(\mathrm{N})$ is often applied at high rates in order to maximize crop yield. With such high rates, the blue water footprint (WF) per unit of crop is low, but the N-related grey WF per unit of crop yield is relatively high. This study explores the trade-off between blue and grey WF at different $\mathrm{N}$-application rates (from 25 to $300 \mathrm{~kg} \mathrm{~N} \mathrm{ha}^{-1} \mathrm{y}^{-1}$ ) under various field management practices. We first analyse this trade-off under a reference management package (applying inorganic- $\mathrm{N}$, conventional tillage, full irrigation). Next, we estimate the economically optimal $\mathrm{N}$-application rate when putting a price to pollution. Finally, we consider the blue-grey WF trade-off for other management packages, a combination of inorganic- $\mathrm{N}$ or organic- $\mathrm{N}$ with conventional tillage or no-tillage, and full or deficit irrigation. We use the APEX model to simulate soil water and $\mathrm{N}$ balances and crop growth. As a case study, we consider irrigated maize on loam soil for the period 1998-2012 in a semi-arid environment in Spain. The results for the reference package show that increasing $\mathrm{N}$ application from 50 to $200 \mathrm{~kg} \mathrm{~N} \mathrm{ha}^{-1}$, with crop yield growing by a factor 3, involves a trade-off, whereby the blue WF per tonne declines by $60 \%$ but the N-related grey WF increases by $210 \%$. Increasing $\mathrm{N}$ application from 25 to $50 \mathrm{~kg} \mathrm{~N} \mathrm{ha}^{-1}$, with yield increasing by a factor 2, is a no-regret move, because blue and grey WFs per tonne are reduced by $40 \%$ and $8 \%$, respectively. Decreasing $\mathrm{N}$ application from 300 to $200 \mathrm{~kg} \mathrm{~N}^{-1}$ is a no-regret move as well. The minimum blue WF per tonne is found at $\mathrm{N}$ application of $200 \mathrm{~kg} \mathrm{~N} \mathrm{ha}^{-1}$, with a price of $8 \$ \mathrm{~kg}^{-1}$ of $\mathrm{N}$ load to water pollution the economically optimal $\mathrm{N}$-application rate is $150 \mathrm{~kg} \mathrm{~N} \mathrm{ha}^{-1}$.

(c) 2018 Elsevier B.V. All rights reserved.

\footnotetext{
* Corresponding author at: Water Resources Management (WRM) Group, Wageningen University, Wageningen, The Netherlands.

E-mail address: abebe.chukalla@wur.nl (A.D. Chukalla).
} 


\section{Introduction}

It has often been argued that increasing crop yield through increased use of inputs (intensification) is preferred over expanding the areal extent of less intensive production methods, in order to fulfil increasing global food demand, as it avoids disruption of the ecosystems and greenhouse gas emissions that come along with enlarging the agricultural area (Edgerton, 2009; Pradhan et al., 2015). In water-scarce areas, intensification is expected to be achieved on existing irrigated areas (Playán and Mateos, 2006). Research on 'closing the yield gap' tends to focus on maximizing land productivity through increasing the necessary inputs. Closing the yield gap, however, requires a careful balance between increasing land productivity and the efficient use of water and nutrients, because a focus on maximizing yields may come at the price of intensified resource use and pollution (Foley et al., 2011). With increasing inputs, the additional yield gain can be steep initially, but becomes less and less at higher input levels. This holds for adding more nutrients (Godard et al., 2008) as well as for adding more irrigation water (Steduto et al., 2012; Amarasinghe and Smakhtin, 2014). While intensification of agriculture comes along with widespread eutrophication of water (Carpenter et al., 1998), it also increasingly faces the problem of limitations in water availability (Davis et al., 2017). It is therefore relevant to consider not only crop yield, but also irrigation water consumption (blue water footprint) per tonne of crop produced and water pollution (grey water footprint) per tonne of crop (Hoekstra et al., 2011).

With increasing irrigation rate, the blue water footprint (WF) per tonne of crop will initially reduce, because of the high marginal yield gain per additional unit of water, but it will start to increase after the point of highest marginal water productivity (Chukalla et al., 2015). Similarly, with increasing $\mathrm{N}$-application rate, the $\mathrm{N}$ load to fresh water per tonne of crop, and thus the grey WF per tonne, may initially decrease, but it will quickly increase at higher $\mathrm{N}$-application rates (Valero et al., 2005; Zhou et al., 2011; Good and Beatty, 2011). Therefore, considerations on intensification are confronted with trade-offs between crop yield (and linked to it revenue per hectare) and environmental impacts (blue and grey WF).

The intensity of irrigation links to the blue WF and the intensity of $\mathrm{N}$ inputs to the grey WF. Crop yields depend on the combination of $\mathrm{N}$ and irrigation water inputs, however, so that the blue WF per tonne also depends on the N-application rate, and the grey WF per tonne also depends on the irrigation water volume applied. Previous studies show that increasing the irrigation rate may increase nitrogen productivity and increasing the $\mathrm{N}$-application rate may increase water productivity (McMaster et al., 2005; Molden et al., 2010; Al-Kaisi and Yin, 2003). Other studies show that N leaching, and thus the grey WF per tonne, increases not only with $\mathrm{N}$-application rate, but also with irrigation (Valero et al., 2005; Schröder et al., 2007; Al-Kaisi and Yin, 2003). A smart combination of management practices can increase the efficient use of both water and $\mathrm{N}$ fertilizer, by reducing unproductive losses like soil evaporation and $\mathrm{N}$ losses to freshwater and the atmosphere (Zhou et al., 2011; Carpenter et al., 1998). Important managerial factors include the irrigation technique and application strategy, the mulching practice and the tillage practice (Chukalla et al., 2015; Derpsch et al., 2010; Grandy et al., 2006; Huang et al., 2015). Some earlier studies provide insight in the effect of individual or combined management practices on the blue WF per tonne, or the $\mathrm{N}$ load to freshwater, but do not consider trade-offs that may occur between the blue and grey WF in crop production. The current study focuses on this blue-grey WF trade-off. Since experimental field studies are expensive in terms of time and resources when one wants to study a wide variety of management conditions, we have chosen here a model-based approach to study water and nutrient balances and crop growth.

The objective of the current study is to explore the trade-off between the blue and N-related grey WF per tonne of crop at different N-application rates, under various field management practices. As a reference, we consider the common combination of applying inorganic- $\mathrm{N}$, conventional tillage and full irrigation. We study other management packages by changing the form of fertilizer (inorganic-N or organic-N), the tillage practice (conventional or no-tillage) and the irrigation strategy (full or deficit irrigation). As a case study, we consider irrigated maize over a 15-years period (1998-2012) on a loam soil in Badajoz, Spain, which is a semi-arid environment. We use the Agricultural Policy and Environmental eXtender (APEX) model, which simulates water and nutrient balances and crop growth (Williams and Izaurralde, 2006). This model is able to successfully simulate the effect of a wide array of field management practices (Wang et al., 2012; Gassman et al., 2010; Gaiser et al., 2010), and has been applied for a wide range of environments, including semi-arid conditions in Spain (Cavero et al., 2012).

This is the first study assessing the trade-off between water depletion (blue WF) and water pollution (grey WF). By fully elaborating one case study we intend to show the feasibility of quantifying the effect of relevant soil, water and nutrient management interventions on both blue and grey WF and the feasibility of identifying which measures are no-regret (reducing both blue and grey WF) and which measures imply a trade-off. In addition, we explore how putting a price to pollution can alter a farmer's decision on the amount of $\mathrm{N}$ fertilizer to use and thus its effect on water depletion and water pollution. We do not expect that the quantitative findings can immediately be generalized to other crops and environments, but we expect that the methodological approach introduced here for one case study can be extended for other crops and environments and thus provide a basis for further study.

\section{Method and data}

\subsection{Research set-up}

We use the APEX model to simulate the effect of seven nitrogen application rates on evapotranspiration, $\mathrm{N}$ load to freshwater, and crop yield, and subsequently compute the resultant blue and N-related grey water footprints. We do this for eight field management packages, which results in 56 simulations altogether (Fig. 1). Each management package constitutes of a combination of management practices: application of inorganic-N or organic-N, no-tillage or conventional tillage, and full or deficit irrigation. The combination of inorganic-N fertilizer with conventional tillage and full irrigation is assumed as a reference management package.

The rate of $\mathrm{N}$ application from livestock manure in $\mathrm{EU}$ member states is legally restricted by the EU Nitrates Directive to $170 \mathrm{~kg} \mathrm{~N} \mathrm{ha}^{-1} \mathrm{y}^{-1}$, or in case of derogation up to $250 \mathrm{~kg} \mathrm{~N} \mathrm{ha}^{-1}$ (Van Grinsven et al., 2012; Amery and Schoumans, 2014). However, surveys in Spain show that application rates of $300-350 \mathrm{~kg} \mathrm{~N} \mathrm{ha}^{-1} \mathrm{y}^{-1}$ are still common to cultivate maize in the Ebro Valley (Berenguer et al., 2009) and up to $300 \mathrm{~kg} \mathrm{~N} \mathrm{ha}^{-1}$ in La Mancha (Valero et al., 2005). In our simulations, we therefore use $300 \mathrm{~kg} \mathrm{~N} \mathrm{ha}^{-1}$ as an upper value for the $\mathrm{N}$-application rate.

\subsection{Soil water and nitrogen balances and crop growth simulation}

The soil water and nitrogen balances and crop growth under different conditions are simulated with a daily time step using APEX, a dynamic, deterministic and physical-based model (Williams and Izaurralde, 2006). A brief summary of the processes simulated in the APEX model, provided in detail in the documentation of APEX (Williams et al., 2008), is given below.

In the water balance routines, the incoming rainfall or irrigation is partitioned between surface runoff and infiltration. Infiltrated water partly gets stored in the soil profile, partly gets lost via evapotranspiration (ET), partly percolates vertically to groundwater, and partly flows out laterally, eventually splitting up into quick return flow and lateral subsurface flow. 


\begin{tabular}{|c|c|c|}
\hline $\begin{array}{l}\text { Seven nitrogen application rates: } \\
25,50,100,150,200,250 \text { or } 300 \mathrm{~kg} \mathrm{~N} \mathrm{ha}^{-1}\end{array}$ & APEX model & $\begin{array}{l}\text { Nitrogen load to freshwater } \\
\text { Evapotranspiration } \\
\text { Crop yield }\end{array}$ \\
\hline $\begin{array}{l}\text { Eight field management packages, each one defined } \\
\text { by a combination of: } \\
\text { - Nitrogen form: inorganic-N or organic-N } \\
\text { - Tillage practice: no-tillage or conventional tillage } \\
\text { - Irrigation strategy: full or deficit irrigation }\end{array}$ & & $\begin{array}{l}\text { Blue \& N-related grey WF per } \\
\text { unit of crop }\end{array}$ \\
\hline
\end{tabular}

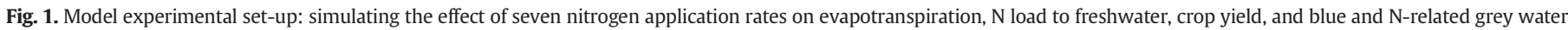
footprint, under eight field management packages. (For interpretation of the references to colour in this figure legend, the reader is referred to the web version of this article.)

In the $\mathrm{N}$ balance calculation, APEX considers $\mathrm{N}$ addition to the soil in the form of anthropogenic $\mathrm{N}$ fertilizer and $\mathrm{N}$ manure addition, as well as atmospheric dry and wet $\mathrm{N}$ deposition. $\mathrm{N}$ out-fluxes from the root zone to the atmosphere included are denitrification and volatilization. Outfluxes to the freshwater body concern $\mathrm{N}$ dissolved in runoff, quick return flow, lateral subsurface flow and percolation, and $\mathrm{N}$ adsorbed to sediments, while another out-flux describes $\mathrm{N}$ harvested with the crop. Simulated N transformations concern mineralization, immobilization, and nitrification.

APEX simulates the potential crop growth based on the interception of active radiation by the plant canopy, which is characterized by the leaf area index (Williams et al., 1989). Phenological development of the crop is based on daily heat unit accumulation from planting to harvest date, or until the accumulated heat units equal the potential heat units for the crop (Steduto et al., 2012; McMaster et al., 2005). Actual daily crop growth is constrained by the most limiting of four stress factors modelled (water, temperature, $\mathrm{N}$-fertilizer, and aeration in the root zone). The marketable yield is obtained by multiplying the aboveground biomass with a harvest index, which may be affected by water stress and growing season length.

$\mathrm{N}$ application just before or during the growing season is done in two rounds. In the first round, $30 \%$ of the total is applied. Inorganic N is applied through broadcasting at planting; organic $\mathrm{N}$ (manure) is applied through injection 15 days before planting. In the second round, in which the remaining $70 \%$ of the total is put on the field, both forms of $\mathrm{N}$ fertilizer are applied as side-dressing one month after planting. The inorganic $\mathrm{N}$ is assumed to be in the form of nitrate. The manure composition is assumed as in the APEX database, as $91.7 \%$ organic $\mathrm{N}$ and $8.3 \%$ inorganic-N.

Conventional tillage is simulated as two times ploughing to a depth of $20 \mathrm{~cm}$ at thirty and fifteen days before sowing date, and one time harrowing following the emergence of the seed. The two times ploughing is in the range of the common one to three times tilling (Nagy and Rátonyi, 2013; FAO, 2016); the ploughing depth of $20 \mathrm{~cm}$ is the average estimate reported by Townsend et al. (2015) and FAO (2016). No-tillage, a form of conservation tillage encouraged by the EU agricultural policy (De Vita et al., 2007), is simulated as no soil disturbance; crop residues are kept on the field giving year-round soil cover.

Full irrigation is simulated by supplying irrigation water when the soil moisture content in the root zone would otherwise drop below a level at which water stress occurs, and irrigating a volume that raises the soil moisture content to field capacity. Deficit irrigation is simulated by allowing the soil moisture to drop to a level where the crop is moderately water-stressed $(20 \%$ plant water stress level in APEX); when that level is reached, irrigation is done to bring the soil moisture to field capacity. In this manner, soil water deficits can reach up to $61-100 \%$ of total ET over the growing period (Fereres and Soriano, 2007). We assume the use of furrow irrigation, the dominant irrigation technique in the EU in 2010, particularly in the Eastern and Mediterranean parts of Europe (EUROSTAT, 2016).
APEX uses a soil-organic-matter model to simulate the coupled cycling of $\mathrm{C}$ and $\mathrm{N}$ in the soil, and thus to simulate the decomposition of organic residues (plant residues, roots, and manure) (Parton et al., 1994; Williams and Izaurralde, 2006). Plant residues (shoots and roots) are partitioned into structural (resistant to decomposition) and metabolic (readily decomposable) plant material as a function of the residue's carbon to nitrogen ratio. The decomposition rates of the different pools are simulated by considering water and temperaturecontrolled factors. Organic materials from surface litter move to subsurface layers by leaching equations, in the absence of tillage. The role of tillage as it is implemented in APEX is to mix nutrients and crop residues within the tillage depth. Under no-tillage, leaching is the only cause that drives the crop residue downward, and thus the decomposed organic matter is cumulated close to the top surface of the soil.

\subsection{Blue and grey water footprints of growing crops}

The blue and grey water footprint (WF) of crop production is indicators of the consumption and pollution, respectively, of groundwater or surface water (Hoekstra, 2017). The blue WF of crop production is defined as the volume of irrigation water consumed (evaporated or incorporated into the crop) in the process of growing crops (Hoekstra et al., 2011). The blue WF per area is calculated by accumulating the daily blue evapotranspiration (ET) during the crop growing season, expressed as a volume per ha. The blue WF per unit of harvested crop is calculated as the ratio of accumulated blue ET to crop yield, expressed as a volume per tonne of crop. Blue ET is the ET from irrigation water, which is estimated at daily resolution by multiplying ET by the fraction of blue water in the total soil water content in the root zone (Chukalla et al., 2015).

The grey WF of crop production is defined as the volume of freshwater needed to assimilate the load of pollutants, emitted through the production process, based on natural background and existing ambient water quality standards. The N-related grey WF per area (in volume per ha per year) is calculated by dividing the accumulated daily simulated $\mathrm{N}$ loads to freshwater by the difference between the ambient water quality standard for that pollutant (the maximum acceptable concentration) and its natural concentration in the receiving water body (Hoekstra et al., 2011). The grey WF per unit of product is expressed in volume per tonne of crop by dividing the grey WF per area by the marketable crop yield (tonne). A maximum acceptable $\mathrm{N}$ concentration of $50 \mathrm{mg}$ nitrate- $\mathrm{N} \mathrm{L}^{-1}$ (or $11.3 \mathrm{mg} \mathrm{N} \mathrm{L}^{-1}$ ) is adopted, based on the EU Nitrates Directive (Monteny, 2001). The natural concentration was considered to be $0.5 \mathrm{mg} \mathrm{N} \mathrm{L}^{-1}$, following for example de Miguel et al. (2015).

\subsection{Benefit versus cost associated with increasing nitrogen application when putting a price to pollution}

We analyse when additional revenues of $\mathrm{N}$ application (because of increased crop yield) outweigh the cost associated with additional $\mathrm{N}$ application (because of increased $\mathrm{N}$ and irrigation water costs and 
because of increased water pollution). The gross revenue of crop production $\left(\$ \mathrm{ha}^{-1} \mathrm{y}^{-1}\right)$ is calculated at different $\mathrm{N}$-application rates in case of the reference management package by multiplying crop yield (tonne ha ${ }^{-1} \mathrm{y}^{-1}$ ) and the price of the crop $\left(\$\right.$ tonne $\mathrm{C}^{-1}$ ). The cost of $\mathrm{N}$ $\mathrm{ha}^{-1}$ for each $\mathrm{N}$-application rate is calculated by multiplying the $\mathrm{N}$ application rate $\left(\mathrm{kg} \mathrm{N} \mathrm{ha}^{-1} \mathrm{y}^{-1}\right)$ by the price of fertilizer $\left(\$ \mathrm{~kg}^{-1}\right)$. At increasing $\mathrm{N}$-application rates, irrigation water application is higher as well, because of the better crop growth and associated additional transpiration of the plants; the cost of the irrigation water per ha for each $\mathrm{N}$-application rate is calculated by multiplying the total volume of irrigation water used $\left(\mathrm{m}^{3} \mathrm{ha}^{-1} \mathrm{y}^{-1}\right)$ by the price of water $\left(\$ \mathrm{~m}^{-3}\right)$. The cost of water pollution is expressed in terms of a price to the $\mathrm{N}$ load to water $\left(\$ \mathrm{~kg}^{-1}\right)$. We gradually increase this price, starting from zero, to find at what level, a price of water pollution will lower the economically optimum $\mathrm{N}$-application rate.

\subsection{Data}

While we simulate the full consecutive period 1993-2012, we show results based on average values over the period 1998-2012, excluding the first five years of the simulation, which was identified as the warm-up period using graphical time-series inspection (Robinson, 2002). Climatic and soil data as input to the APEX model were collected for Badajoz in Spain $\left(38.88^{\circ} \mathrm{N},-6.83^{\circ} \mathrm{E}\right)$. Observed weather data that include daily minimum and maximum temperatures, and rainfall for 1993 to 2012 were extracted from the European Climate Assessment and Dataset (Klein Tank et al., 2002). Mean monthly wind speed data were taken from FAO's CLIMWAT database (Smith, 1993). Physical and chemical characteristics of the soil used in APEX are extracted from the European Soil Database (ESD) (Hannam et al., 2009). Soil texture at our study site is classified as loam soil, based on the relative fractions of sand, silt and clay in the soil and using the Soil Texture Triangle Calculator (Saxton et al., 1986). A loam soil albedo of 0.13, at field capacity, is used in APEX (Sumner, 1999). Soil moisture content is initialised using the standard procedure in APEX, based on average annual rainfall within the simulation period. Soil nutrient content (nitrogen, phosphorus, carbon) is initialised in APEX using the data extracted from the ESD. We adjusted the initial organic-N content for each simulation so that there is zero $\mathrm{N}$ build-up in the root zone over the simulation period of twenty years. We use default values for the crop parameters in the APEX model (Fader et al., 2015; Davis et al., 1988). The cost of irrigation water is assumed at $0.05 \$ \mathrm{~m}^{-3}$, which is within the range of 0.01 to $0.11 \$ \mathrm{~m}^{-3}$ reported by Gómez-Limón and Riesgo (2004) for Spain. The cost of $\mathrm{N}$ fertilizer is assumed $0.09 \$ \mathrm{~kg}^{-1}$ (Martínez and Albiac, 2006). We use a price of harvested maize of $264 \$$ tonne $^{-1}$, which is the average of the reported annual prices over the period 2010-2015 in Spain (FAOSTAT, 2017).

\section{Results}

3.1. Trade-off between blue and grey WF under the reference management package

Fig. 2 shows evapotranspiration (ET) from the crop field, $\mathrm{N}$ load to groundwater and surface water, and maize yield as a function of the $\mathrm{N}$-application rate for the reference management package (inorganic$\mathrm{N}$; conventional tillage; full irrigation). As shown, total ET is the sum of green and blue ET, as well as the sum of (unproductive) evaporation (E) and (productive) transpiration (T). Blue ET makes up 75-81\% of ET (with the larger share at higher $\mathrm{N}$-application rates), and $\mathrm{T}$ amounts to $81-89 \%$ of ET (again with the larger share at higher $\mathrm{N}$-application rates). Green ET has a constant value of $144 \mathrm{~mm}$ along the range of $\mathrm{N}$ applications considered. E decreases as a result of increased canopy cover from $113 \mathrm{~mm}$ ( $19 \%$ of ET) at $25 \mathrm{~kg}-\mathrm{N} \mathrm{ha}{ }^{-1}$ to $82 \mathrm{~mm}$ ( $11 \%$ of ET) at 150 $\mathrm{kg}-\mathrm{N} \mathrm{ha}{ }^{-1}$. The $\mathrm{N}$ load to groundwater and surface water consists of two components: the load during the crop growing season and the off-season load. For all N-application rates the off-season load is the main share $(87 \% \pm 3.5 \%)$ of the annual load, due to the absence of $\mathrm{N}$ uptake by the crop in that season.

Fig. 3 shows the green, blue and N-related grey WF per tonne as a function of the $\mathrm{N}$-application rate. At low to intermediate $\mathrm{N}$ application, both green and blue WF per tonne reduce at increasing $\mathrm{N}$-application rates. The green WF per tonne (green ET divided by crop yield) decreases because green ET remains constant while crop yield increases with increasing $\mathrm{N}$ application. The blue WF per tonne (blue ET divided by crop yield) decreases because crop yield increases faster with
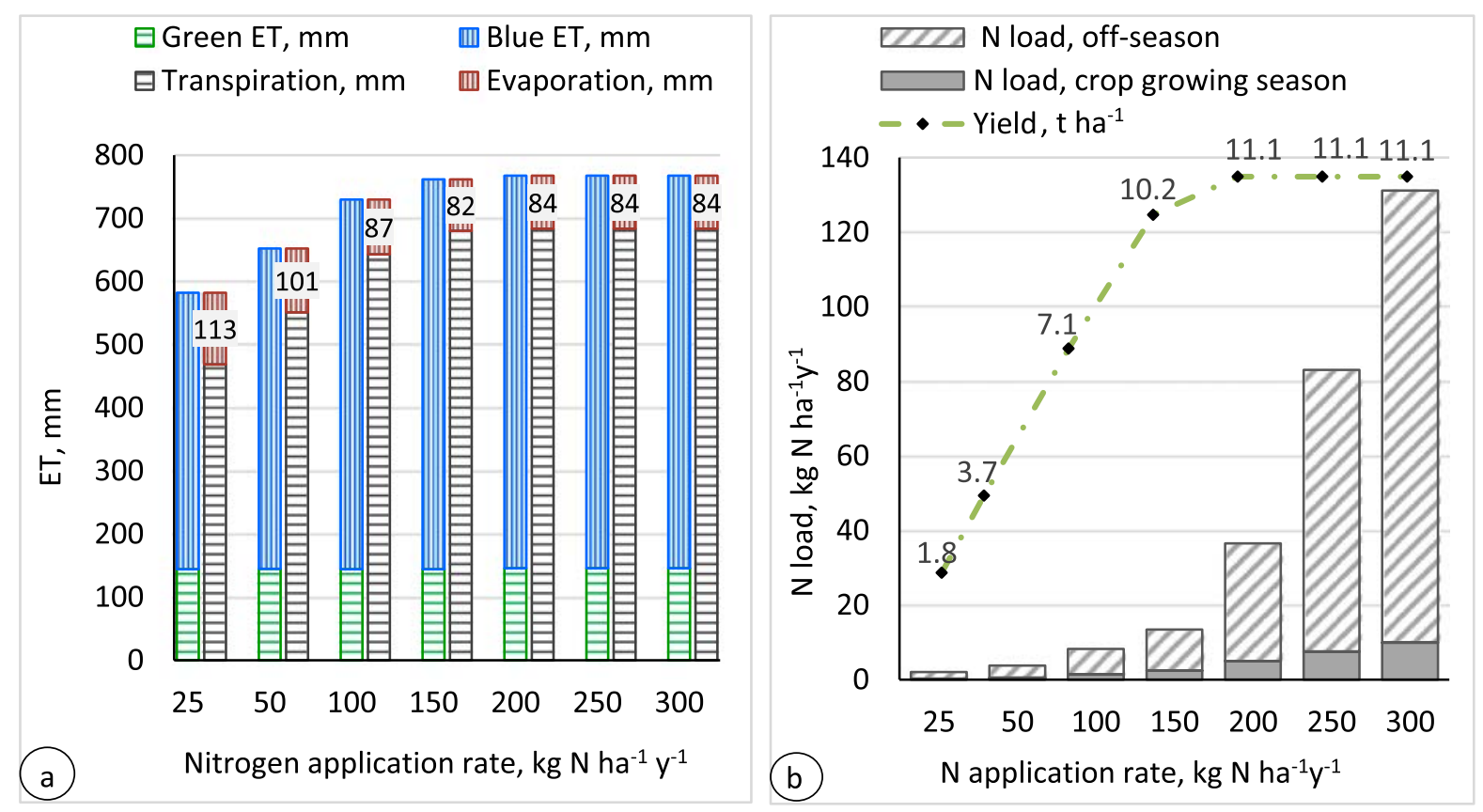

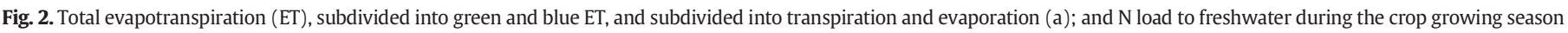

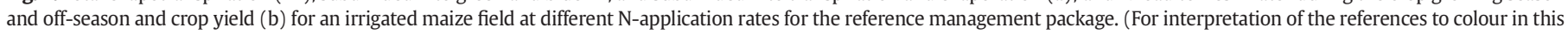
figure legend, the reader is referred to the web version of this article.) 
increasing $\mathrm{N}$ application than blue ET. At high $\mathrm{N}$ application, green and blue ET and yield remain constant, and so do the green and blue WF per tonne.

When increasing the $\mathrm{N}$-application rate while the application rate is still very low (from 25 to $50 \mathrm{~kg} \mathrm{~N} \mathrm{ha}^{-1} \mathrm{y}^{-1}$ ), crop yield increases at a bit faster rate than leaching and runoff of $\mathrm{N}$, so that the N-related grey WF per tonne slightly decreases. At higher $\mathrm{N}$ application, the grey WF per tonne will increase, because the $\mathrm{N}$ load to freshwater increases at a faster rate with increasing $\mathrm{N}$ application than the crop yield. This is particularly the case from $150 \mathrm{~kg} \mathrm{~N} \mathrm{ha}^{-1} \mathrm{y}^{-1}$ onwards. At the higher N-application rates the fraction of applied $\mathrm{N}$ that is taken up by the crop diminishes, while fraction that leaches to groundwater or runs off to surface water increases.

Increasing $\mathrm{N}$ application from 25 to $50 \mathrm{~kg} \mathrm{~N} \mathrm{ha}^{-1} \mathrm{y}^{-1}$, with yield increasing by a factor 2 , is a no-regret move, because blue and grey WFs per tonne are reduced by $40 \%$ and $8 \%$, respectively. Decreasing N application from 300 to $200 \mathrm{~kg} \mathrm{~N} \mathrm{ha}^{-1} \mathrm{y}^{-1}$ is a no-regret move as well, with a grey $\mathrm{WF}$ per tonne reduced by $72 \%$ while the blue WF and yield remain the same. The intermediate $\mathrm{N}$-application range inevitably involves a trade-off between the blue and grey WF per tonne. When $\mathrm{N}$ application increases from 50 to $200 \mathrm{~kg} \mathrm{~N} \mathrm{ha}^{-1} \mathrm{y}^{-1}$, crop yield grows by a factor 3 and the blue WF per tonne declines by $60 \%$, but the grey WF increases by $210 \%$. The minimum blue WF per tonne is found at the $\mathrm{N}$ application $200 \mathrm{~kg} \mathrm{~N} \mathrm{ha}^{-1} \mathrm{y}^{-1}$, while the minimum grey WF per tonne is at $50 \mathrm{~kg} \mathrm{~N} \mathrm{ha}^{-1} \mathrm{y}^{-1}$.

\subsection{Economic optimal nitrogen application rate when including cost of pollution}

For the reference management package, Fig. 4 shows the revenue at increasing $\mathrm{N}$-application rate, as well as the costs of additional inputs ( $\mathrm{N}$-fertilizer and irrigation water). The revenue stabilizes beyond an $\mathrm{N}$-application rate of $200 \mathrm{~kg} \mathrm{~N}^{-1} \mathrm{y}^{-1}$, because yields don't increase beyond that rate. When we look at the gross revenue minus the cost of $\mathrm{N}$ and additional irrigation water, we can see that applying more than $200 \mathrm{~kg} \mathrm{~N} \mathrm{ha}^{-1} \mathrm{y}^{-1}$ is not economical, because net revenue will diminish. When putting a price to water pollution, by introducing a gradually increasing cost per $\mathrm{kg}$ of $\mathrm{N}$ load to freshwater, we find that when the cost reaches $8 \$$ per $\mathrm{kg}$ of $\mathrm{N}$ load to water, the economically optimal $\mathrm{N}$ load shifts from 200 to $150 \mathrm{~kg} \mathrm{~N} \mathrm{ha}^{-1} \mathrm{y}^{-1}$. This cost of $8 \$$ per $\mathrm{kg}$ of $\mathrm{N}$ load can be seen in the context of reported fines for exceedance of application standards of 7 to 11 euro per $\mathrm{kg} \mathrm{N}$ as applied in the Netherlands (Van Grinsven et al., 2016), and reported damage costs of 5 to 24 euro per $\mathrm{kg}$ of $\mathrm{N}$ to water in Europe (Brink et al., 2011). The shift from 200 to $150 \mathrm{~kg} \mathrm{~N} \mathrm{ha}^{-1} \mathrm{y}^{-1}$ as the economically optimal $\mathrm{N}$ load will take place at a lower price of pollution than the $8 \$$ per $\mathrm{kg}$ of $\mathrm{N}$ load if we assume higher prices of $\mathrm{N}$ fertilizer and water than we did (see Section 2.5 ). These findings appear to be insensitive to the prices of $\mathrm{N}$ fertilizer and irrigation water assumed. The largest uncertainty is with the cost of irrigation water, but even if we vary the water price within the broad range of 0.01 to $0.11 \$ \mathrm{~m}^{-3}$ as reported by Gómez-Limón and Riesgo (2004) for Spain, the tipping points will not change from what is presented here.

\subsection{Trade-off between blue and grey WF under different management packages}

Fig. 5 shows the blue versus N-related grey WF per tonne of crop for different $\mathrm{N}$-application rates and field management packages. The figure shows the results of 56 simulations (seven $\mathrm{N}$-application rates $\times$ two forms of $\mathrm{N} \times$ two tillage practices $\times$ two irrigation strategies). The points that have the same combination of $\mathrm{N}$ form, tillage practice and irrigation strategy are connected in the figure by a solid or dashed line. Each line thus shows the effect of a changing $\mathrm{N}$-application rate in case of a fixed management package. The figure demonstrates that the effect of increasing the $\mathrm{N}$-application rate on the blue and grey WF per tonne is similar for all management packages: increasing the rate from 25 to $50 \mathrm{~kg} \mathrm{~N} \mathrm{ha}^{-1} \mathrm{y}^{-1}$ or reducing the rate from 300 to $200 \mathrm{~kg} \mathrm{~N} \mathrm{ha}^{-1} \mathrm{y}^{-1}$ are no-regret moves, as they reduce both blue and grey WF per tonne or just one of them without worsening the other. Changing $\mathrm{N}$-application rates between 50 and $200 \mathrm{~kg} \mathrm{~N} \mathrm{ha}^{-1} \mathrm{y}^{-1}$ always involves a trade-off, reducing blue WF per tonne and increasing grey $\mathrm{WF}$, or vice versa.

The oval shapes in the figure encircle points with a certain fixed $\mathrm{N}$-application rate. Within each oval, crop yields may differ slightly (as indicated), depending on the precise management package, but yield differences at fixed $\mathrm{N}$-application rate are small. Shifting from one management package to another within an oval (a given $\mathrm{N}$-application rate) may lead to a reduction of both blue and grey WF per tonne (no regret), an increase of both (no go), or a decrease in one and increase in the other (trade-off).

There are numerous no-regret moves (relative to the reference package). Most important, for all $\mathrm{N}$-application rates, shifting from the reference package to the combination of organic-N and deficit irrigation (staying with conventional tillage), will result in a blue WF decrease of by $4 \pm 1 \%$ and a grey WF decrease of $17 \pm 7 \%$. For $N$-application rates up to $100 \mathrm{~kg} \mathrm{~N} \mathrm{ha}{ }^{-1} \mathrm{y}^{-1}$, shifting from the reference to deficit irrigation (staying with inorganic-N and conventional tillage) will reduce the blue WF by $10 \pm 1 \%$ and the grey WF by $14 \pm 5 \%$. The same move for $\mathrm{N}$-application rates from $150 \mathrm{~kg} \mathrm{~N} \mathrm{ha}^{-1} \mathrm{y}^{-1}$ or higher involves a trade-off,
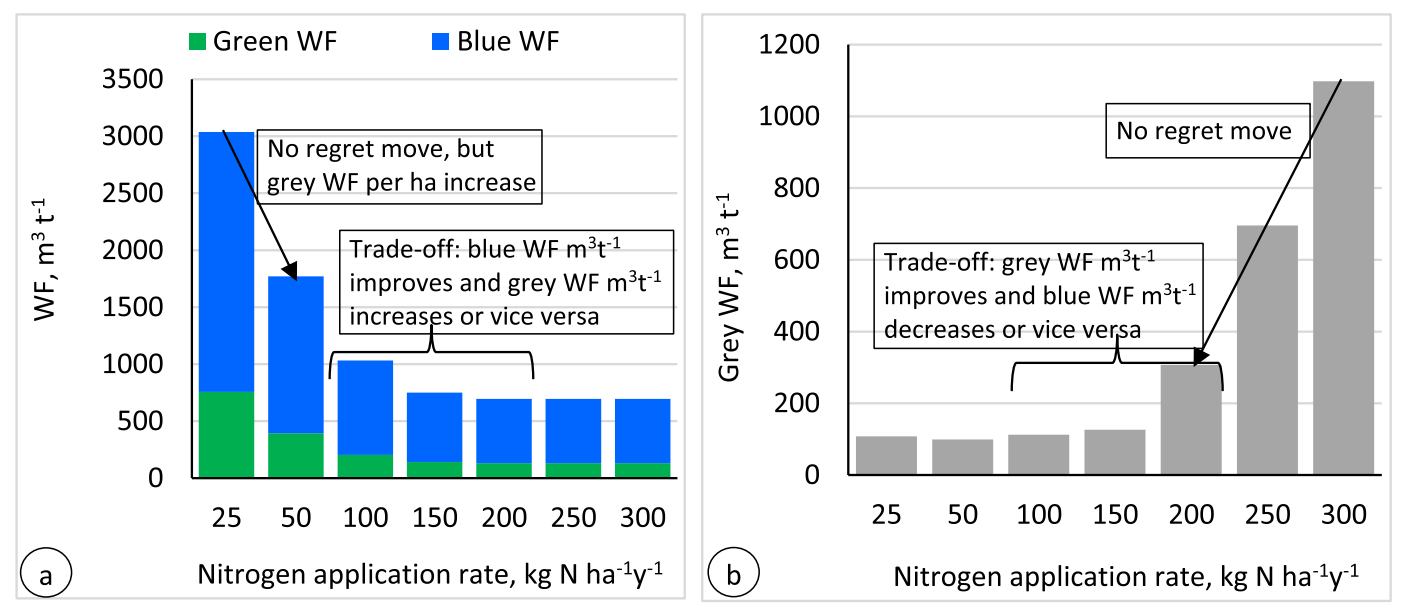

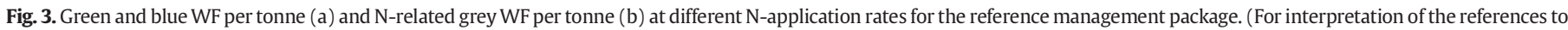
colour in this figure legend, the reader is referred to the web version of this article.) 


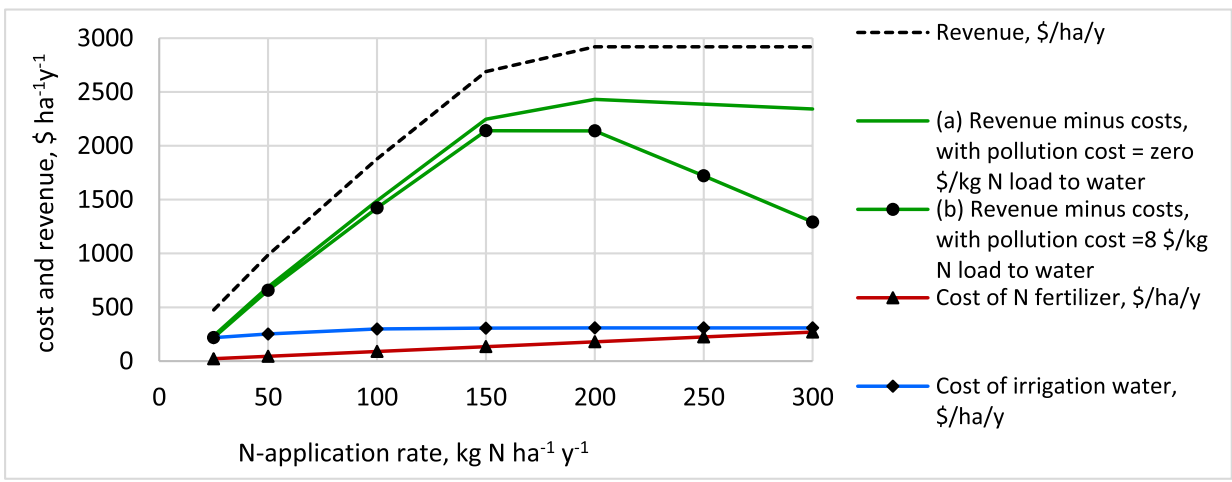

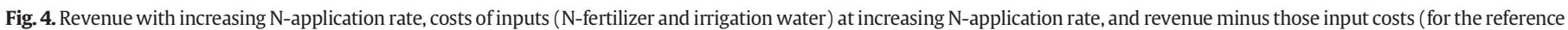
management package). An additional line shows revenue minus input costs when also subtracting a cost of pollution of $8 \$$ per kg of $\mathrm{N}$ load to water.

however: the blue WF per tonne will still reduce (by $5 \pm 2 \%$ ) but the grey WF per tonne will significantly increase (by $24 \pm 12 \%$ ). For N application rates of 200 to $300 \mathrm{~kg} \mathrm{~N} \mathrm{ha}^{-1} \mathrm{y}^{-1}$, there are different possible noregret moves. Moving from the reference to no-tillage will reduce the blue WF by $6 \pm 0 \%$ and the grey WF by $8 \pm 2 \%$. Moving from the reference to organic-N and no-tillage will reduce the blue WF by the same percentage, but the grey WF by $34 \pm 6 \%$. Finally, moving from the reference to the combination of organic-N, no-tillage, and deficit irrigation will reduce the blue WF by $10 \pm 0 \%$ and the grey WF by $18 \pm 4 \%$.

A number of moves will reduce the blue WF per tonne but increase the N-related grey WF per tonne. For all $\mathrm{N}$-application rates, moving from the reference to no-tillage and deficit irrigation (staying with inorganic-N) will reduce the blue WF by $13 \pm 3 \%$ and increase the grey $\mathrm{WF}$ by $29 \pm 18 \%$. For $\mathrm{N}$-application rates up to $150 \mathrm{~kg} \mathrm{~N}^{-1} \mathrm{y}^{-1}$, moving from the reference to organic-N, no-tillage and deficit irrigation will reduce the blue WF by $11 \pm 1 \%$ and increase the grey WF by $21 \pm 8 \%$. For $\mathrm{N}$-application rates from 150 to $300 \mathrm{~kg} \mathrm{~N} \mathrm{ha}^{-1} \mathrm{y}^{-1}$, moving from the reference to deficit irrigation will reduce the blue WF by $5 \pm 2 \%$ and increase the grey WF by $24 \pm 12 \%$.
The opposite, reducing the N-related grey WF per tonne at the cost of a blue WF increase can occur as well. For all N-application rates, moving from the reference to organic- $\mathrm{N}$ (staying with conventional tillage and full irrigation) will reduce the grey WF per tonne by $4 \pm 3 \%$ and increase the blue WF by $23 \pm 12 \%$.

\section{Discussion}

The current study shows how increasing $\mathrm{N}$-application rates in maize production may lead to trade-offs between water consumption (blue WF), water pollution (N-related grey WF) and between WFs and crop yield as well. The optimal level at $\mathrm{N}$ application is different: the minimum water pollution per unit of crop is achieved at an $\mathrm{N}$-application rate of $50 \mathrm{~kg} \mathrm{~N} \mathrm{ha}^{-1} \mathrm{y}^{-1}$; the minimum blue water consumption per unit of crop and maximum yield are at $200 \mathrm{~kg} \mathrm{~N}^{-1} \mathrm{y}^{-1}$. When water pollution costs are considered, the economically optimum $\mathrm{N}$ application is $200 \mathrm{~kg} \mathrm{~N} \mathrm{ha}^{-1} \mathrm{y}^{-1}$ when the pollution costs are lower than $8 \$$ per $\mathrm{kg}$ of $\mathrm{N}$ load and $150 \mathrm{~kg} \mathrm{~N} \mathrm{ha}^{-1} \mathrm{y}^{-1}$ when the pollution cost equals or is larger than $8 \$$ per $\mathrm{kg}$ of $\mathrm{N}$ load.

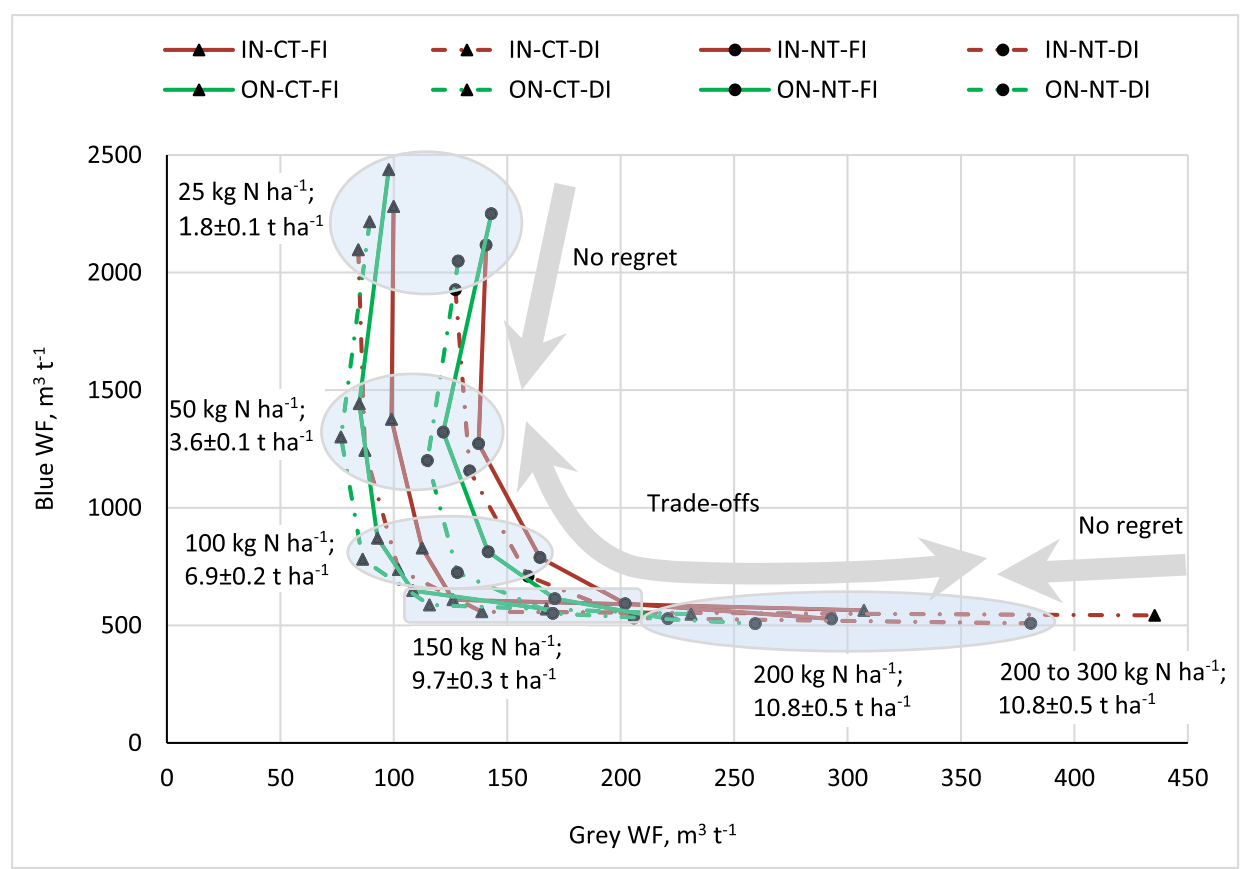

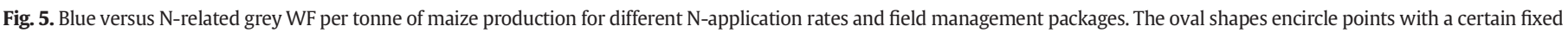

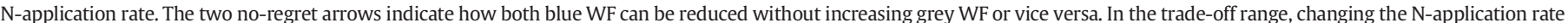

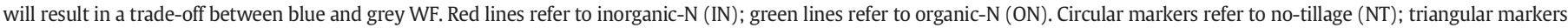

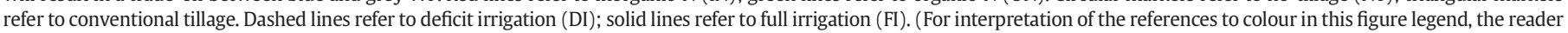
is referred to the web version of this article.) 
The results can be understood by considering $\mathrm{N}$ uptake by the crop and $\mathrm{N}$ surplus in the soil ( $\mathrm{N}$ application minus $\mathrm{N}$ uptake by the crop), the two central variables determining blue and grey WFs in crop production, respectively. $\mathrm{N}$ uptake is important for the development of the plant, which determines ET and crop yield, and thus the blue WF. $\mathrm{N}$ surplus determines $\mathrm{N}$ leaching and runoff, and thus the grey WF. At low $\mathrm{N}$-application rates, most $\mathrm{N}$ is taken up by the plant, so that the $\mathrm{N}$ surplus and thus leaching is small, resulting in a small grey WF. However, at low $\mathrm{N}$ application, nitrogen stress to the plants results in a low crop yield, and thus a large blue WF per tonne. At intermediate Napplication rates, the $\mathrm{N}$ surplus and thus grey WF is increased, but increased $\mathrm{N}$ uptake also results in a better development of the crop and an increased crop yield, thus a smaller blue WF. At high $\mathrm{N}$-application rates, $\mathrm{N}$ uptake, ET and crop yield have reached their maximum levels and the blue WF per tonne is at its minimum level. Adding more $\mathrm{N}$ in the range of high $\mathrm{N}$-application rates, however, will still increase $\mathrm{N}$ leaching, which results in increasing a grey WF per tonne.

Effects of field management practices on the $\mathrm{N}$ and water balances and crop production, as simulated here using APEX, have been discussed extensively in literature. Changes in the form of $\mathrm{N}$ applied, the tillage practice or the irrigation strategy will alter the moisture and nutrient holding capacities of the soil, the rate of soil water movement, and the soil surface cover (crop residue, and crop canopy cover). As a result, the $\mathrm{N}$ load to freshwater (through leaching, runoff and erosion) will be affected, and thus the grey WF per hectare. ET, including the blue ET component, will change as well, and thus the blue WF per hectare. Since also crop yield will be affected, blue and grey WFs per tonne of crop will change as well. Applying organic-N instead of inorganic-N improves the water holding capacity of the soil (Hudson, 1994; Sommerfeldt et al., 1988) and the nutrient retention capacity of the soil as well, which facilitates crop growth and results in increasing ET and blue WF, while N-leaching and thus the grey WF is reduced as a result of the increased nutrient retention capacity. Compared to conventional tillage, no-tillage facilitates the crop residue to remain as a soil cover (mulch) and to reduce unproductive evaporation (De Vita et al., 2007; Mitchell et al., 2012); as a result the blue WF is reduced for all $\mathrm{N}$-application rates. No-tillage enhances nitrogen leaching (Azooz and Arshad, 1996; Triplett and Dick, 2008; Constantin et al., 2010); as a result the grey WF is increased at low N-application rates, where the crop residue is small. At high $\mathrm{N}$-application rates, when the biomass and crop residue are large, no-tillage facilitates the accumulation of soil organic matter that helps to improve the water holding and nutrient retention capacities of the soil; as a result, leaching and grey WF are reduced at high $\mathrm{N}$-application rates. Deficit irrigation instead of full irrigation maintains smaller soil moisture content, which helps to reduce ET and blue WF for all N-application rates. Deficit irrigation reduces percolation (Igbadun, 2012) and N-leaching (Carpenter et al., 1998); as a result the grey WF per tonne is smaller at low N-application rates. At high $\mathrm{N}$-application rates, however, the water stress that comes along with deficit irrigation, hampers $\mathrm{N}$ uptake by the crop; this results in a higher $\mathrm{N}$ surplus in the soil, which increases leaching and the grey WF per tonne.

There is a comparable crop yield response to $\mathrm{N}$ uptake by the crop between our model study with APEX and the field study by Berenguer et al. (2009), both of which are for maize and for similar conditions in Spain. The crop yield response for a given N input in our study is $25 \%$ less than the yield response in the study by Berenguer et al. (2009), which may be due to the high yielding maize variety used in their study.

The WF estimates presented and the $\mathrm{N}$-application rates at which we find minimum water consumption and pollution per tonne of crop depend on the climate, soil, crop type and crop variety assumed in this study, as well on the model used. Similarly, the assumed market value of the crop, costs of $\mathrm{N}$ and irrigation water, and the price put to water pollution all affect the calculated economically optimum $\mathrm{N}$-application rate. Furthermore, the grey WF of growing maize, based in this study on the $\mathrm{N}$ load to freshwater, may increase if other pollutants such as phosphorous and pesticides are considered as well. We did not perform sensitivity analyses for input data used or carry out full uncertainty analyses, which both would be interesting. Also, we did not conduct field experiments, which would be relevant to validate the simulated results with field data, and could be instrumental in validating the models. Therefore, the precise values presented should be taken with caution; the reported values are rather to be understood as illustrative of how different nitrogen application rates and field management practices can affect the trade-offs between water consumption and water pollution.

The systematic approach in the current study can be replicated for other crops, locations, climates, soils, and management options. Other management options that could be studied include different forms of crop management (crop rotation, optimal plant density, intercropping, early sowing, cover crops, improved crop varieties), nutrient management (placement methods, split application, use of slow or controlled release, use of precision fertigation, considering the expected weather and mineralization, denitrification walls), water management (irrigation techniques such as drip or sub-subsurface drip, controlled drainage), soil management (mulching) and landscape management (buffer strips, forest riparian zones).

\section{Conclusion}

This paper explores the trade-offs involved at different $\mathrm{N}$-application rates in a case of maize production at a selected site in Spain. For the reference management package (inorganic $\mathrm{N}$ fertilizer, conventional tillage and full irrigation), different optimum $\mathrm{N}$-application rates are identified. Water pollution (N-related grey WF) per tonne of crop is lowest at $50 \mathrm{~kg} \mathrm{~N} \mathrm{ha}^{-1} \mathrm{y}^{-1}$. Irrigation water consumption (blue WF) per tonne is lowest at $200 \mathrm{~kg} \mathrm{~N} \mathrm{ha}^{-1} \mathrm{y}^{-1}$. The economically optimal $\mathrm{N}$-application rate is at $200 \mathrm{~kg} \mathrm{~N} \mathrm{ha}^{-1} \mathrm{y}^{-1}$ as well, but only if the cost of water pollution resulting from $\mathrm{N}$ leaching and runoff is not included in the calculation. When water pollution is included in the computation and when the cost of the $N$ load to freshwater exceeds $8 \$ \mathrm{ha}^{-1} \mathrm{y}^{-1}$, the optimal $\mathrm{N}$-application rate is reduced to $150 \mathrm{~kg} \mathrm{~N} \mathrm{ha}^{-1} \mathrm{y}^{-1}$. If we consider water pollution and water consumption per hectare rather than per unit of crop produced, we find yet other optimum $\mathrm{N}$-application rates. Water pollution ( $\mathrm{N}$-related grey $\mathrm{WF}$ ) per hectare is lowest at 0 $\mathrm{kg} \mathrm{N} \mathrm{ha}^{-1} \mathrm{y}^{-1}$, while irrigation water consumption (blue WF) per hectare does not depend much on the $\mathrm{N}$-application rate. The additional blue WF per hectare slightly increases with increasing $\mathrm{N}$-application rate, because of the improved growing conditions and the resultant increased transpiration. However, lowering the blue WF per hectare is done more effectively (and without so much impact on the yield) by improved the irrigation technology and irrigation water application strategy (Chukalla et al., 2015).

No single optimal $\mathrm{N}$-application rate can be identified. It depends on the crop, the local environmental conditions, the management practice (e.g. nitrogen form, tillage practice, and irrigation strategy) and what variable is considered: blue or grey WF, per tonne or per hectare, or the economic optimum. In the latter case, it depends on whether the environmental cost of water pollution is included in the computation and, if so, what price is assumed. Local considerations on water pollution and water scarcity levels may influence how the different variables are weighted.

Considering the trade-off between blue and grey WF per tonne of crop associated with choosing an $\mathrm{N}$-application rate, we have identified three typical cases: the no-regret move when increasing $\mathrm{N}$ application at very low rates, the no-regret move when decreasing $\mathrm{N}$ application at very high rates, and case where a trade-off is inevitable, at intermediate $\mathrm{N}$-application rates.

Changing the form of $\mathrm{N}$ applied, the tillage practice or the irrigation strategy, at a given fixed $\mathrm{N}$-application rate, may imply a trade-off between blue and grey WF per tonne of crop as well. However, there are also no-regret moves. Moving from the reference 
to deficit irrigation is a no-regret move for $\mathrm{N}$-application rates up to $100 \mathrm{~kg} \mathrm{~N} \mathrm{ha}{ }^{-1} \mathrm{y}^{-1}$, but involves a trade-off for $\mathrm{N}$-application rates from 150 to $300 \mathrm{~kg} \mathrm{~N} \mathrm{ha}^{-1} \mathrm{y}^{-1}$ : the blue WF per tonne will reduce but the grey WF per tonne will significantly increase. Moving from the reference to organic-N involves a trade-off, for all $\mathrm{N}$-application rates: the grey WF per tonne will get reduced, but (particularly at $\mathrm{N}$-application rates up to $150 \mathrm{~kg} \mathrm{~N} \mathrm{ha}^{-1} \mathrm{y}^{-1}$ ) the blue WF per tonne will increase. Moving from the reference package towards a combination of organic-N and deficit irrigation is a no-regret move, for all N-application rates, as it reduces both blue and grey WF per tonne. Shifting from the reference package towards no-tillage at high $\mathrm{N}$-application rates of $200-300 \mathrm{~kg} \mathrm{~N} \mathrm{ha}^{-1} \mathrm{y}^{-1}$ is a no-regret move, since it reduces both blue and grey WF per tonne. Shifting from the reference to no-tillage at all other $\mathrm{N}$-application rates, however, implies a trade-off, whereby the blue WF per tonne is reduced, but the grey WF per tonne increased.

\section{Acknowledgments}

This research was conducted as part of the EU-FP7-funded project FIGARO (311903). The paper was partially developed within the framework of the Panta Rhei Research Initiative of the International Association of Hydrological Sciences (IAHS).

\section{References}

Al-Kaisi, M.M., Yin, X., 2003. Effects of nitrogen rate, irrigation rate, and plant population on corn yield and water use efficiency. Agron. J. 95, 1475-1482.

Amarasinghe, U.A., Smakhtin, V., 2014. Water productivity and water footprint: misguided concepts or useful tools in water management and policy? Water Int. 1-18.

Amery, F., Schoumans, O., 2014. Agricultural Phosphorus Legislation in Europe, Institute for Agricultural and Fisheries Research (ILVO).

Azooz, R., Arshad, M., 1996. Soil infiltration and hydraulic conductivity under long-term no-tillage and conventional tillage systems. Can. J. Soil Sci. 76, 143-152.

Berenguer, P., Santiveri, F., Boixadera, J., Lloveras, J., 2009. Nitrogen fertilisation of irrigated maize under Mediterranean conditions. Eur. J. Agron. 30, 163-171.

Brink, C., Jacobsen, B.H., Rabl, A., Gren, M., Holland, M., Klimont, Z., Hicks, K., Brouwer, R. Dickens, R., Willems, J., 2011. Costs and benefits of nitrogen in the environment. European Nitrogen Assessment. Cambridge University Press, pp. 513-540.

Carpenter, S.R., Caraco, N.F., Correll, D.L., Howarth, R.W., Sharpley, A.N., Smith, V.H., 1998. Nonpoint pollution of surface waters with phosphorus and nitrogen. Ecol. Appl. 8, 559-568.

Cavero, J., Barros, R., Sellam, F., Topcu, S., Isidoro, D., Hartani, T., Lounis, A., Ibrikci, H., Cetin, M., Williams, J., 2012. APEX simulation of best irrigation and N management strategies for off-site $\mathrm{N}$ pollution control in three Mediterranean irrigated watersheds. Agric. Water Manag. 103, 88-99.

Chukalla, A.D., Krol, M.S., Hoekstra, A.Y., 2015. Green and blue water footprint reduction in irrigated agriculture: effect of irrigation techniques, irrigation strategies and mulching. Hydrol. Earth Syst. Sci. 19, 4877-4891.

Constantin, J., Mary, B., Laurent, F., Aubrion, G., Fontaine, A., Kerveillant, P., Beaudoin, N., 2010. Effects of catch crops, no till and reduced nitrogen fertilization on nitrogen leaching and balance in three long-term experiments. Agric. Ecosyst. Environ. 135, 268-278.

Davis, D., Brewbaker, J., Kaukis, K., 1988. Registration of NE-HY-13A and NE-HY-13B complementary populations of sugary maize germplasm. Crop Sci. 28, 381.

Davis, K.F., Rulli, M.C., Garrassino, F., Chiarelli, D., Seveso, A., D'Odorico, P., 2017. Water limits to closing yield gaps. Adv. Water Resour. 99, 67-75.

de Miguel, Á., Hoekstra, A.Y., García-Calvo, E., 2015. Sustainability of the water footprint of the Spanish pork industry. Ecol. Indic. 57, 465-474.

De Vita, P., Di Paolo, E., Fecondo, G., Di Fonzo, N., Pisante, M., 2007. No-tillage and conventional tillage effects on durum wheat yield, grain quality and soil moisture content in southern Italy. Soil Tillage Res. 92, 69-78.

Derpsch, R., Friedrich, T., Kassam, A., Li, H., 2010. Current status of adoption of no-till farming in the world and some of its main benefits. Int. J. Agric. Biol. Eng. 3, 1-25.

Edgerton, M.D., 2009. Increasing crop productivity to meet global needs for feed, food, and fuel. Plant Physiol. 149, 7-13.

EUROSTAT, 2016. EUROSTAT online database. (European Commission, Luxembourg), Agri-environmental indicator - Irrigation methods http://epp.eurostat.ec.europa.eu last access: October 2016.

Fader, M., Von Bloh, W., Shi, S., Bondeau, A., Cramer, W., 2015. Modelling Mediterranean agro-ecosystems by including agricultural trees in the LPJmL model. Geosci. Model Dev. 8, 3545-3561.

FAO, 2016. On-line Database, Suitable Methods of Tillage for the Farm. Food and Agricultural Orgnization, Rome, Italy http://www.fao.org/docrep/006/y5146e/ y5146e08.htm (last access: November).

FAOSTAT: On-line Database, Food and Agricultrural Organisation Price Statistics, 2015, https://knoema.com/FAOPS2015July/fao-price-statistics-2015, (last access: April), 2017.
Fereres, E., Soriano, M.A., 2007. Deficit irrigation for reducing agricultural water use. J. Exp. Bot. 58, 147-159.

Foley, J.A., Ramankutty, N., Brauman, K.A., Cassidy, E.S., Gerber, J.S., Johnston, M., Mueller, N.D., O'Connell, C., Ray, D.K., West, P.C., 2011. Solutions for a cultivated planet. Nature 478, 337-342.

Gaiser, T., de Barros, I., Sereke, F., Lange, F.-M., 2010. Validation and reliability of the EPIC model to simulate maize production in small-holder farming systems in tropical subhumid West Africa and semi-arid Brazil. Agric. Ecosyst. Environ. 135, 318-327.

Gassman, P., Williams, J., Wang, X., Saleh, A., Osei, E., Hauck, L., Izaurralde, R., Flowers, J., 2010. Invited review article: the agricultural policy/environmental eXtender (APEX) model: an emerging tool for landscape and watershed environmental analyses. T Asabe 53, 711-740.

Godard, C., Roger-Estrade, J., Jayet, P.-A., Brisson, N., Le Bas, C., 2008. Use of available information at a European level to construct crop nitrogen response curves for the regions of the EU. Agric. Syst. 97, 68-82.

Gómez-Limón, J.A., Riesgo, L., 2004. Irrigation water pricing: differential impacts on irrigated farms. Agric. Econ. 31, 47-66.

Good, A.G., Beatty, P.H., 2011. Fertilizing nature: a tragedy of excess in the commons. PLoS Biol. 9, e1001124.

Grandy, A., Robertson, G., Thelen, K., 2006. Do productivity and environmental trade-offs justify periodically cultivating no-till cropping systems? Agron. J. 98, 1377-1383.

Hannam, J.A., Hollis, J.M., Jones, R.J.A., Bellamy, P.H., Hayes, S.E., Liedekerke, M.H., Montanarella, L., 2009. SPE-2: The soil profile analytical database for Europe, Beta Version 2.0. http://esdac.jrc.ec.europa.eu/content/european-soil-database-v20-vector-and-attribute-data, Accessed date: 16 June 2014.

Hoekstra, A.Y., 2017. Water footprint assessment: evolvement of a new research field. Water Resour. Manag. 1-21.

Hoekstra, A.Y., Chapagain, A.K., Aldaya, M.M., Mekonnen, M.M., 2011. The Water Footprint Assessment Manual: Setting the Global Standard. Earthscan, London, UK.

Huang, M., Liang, T., Wang, L., Zhou, C., 2015. No-tillage and fertilization management on crop yields and nitrate leaching in North China Plain. Ecol. Evol. 5, 1143-1155.

Hudson, B.D., 1994. Soil organic matter and available water capacity. J. Soil Water Conserv, 49, 189-194

Igbadun, H., 2012. Impact of methods of administering growth-stage deficit irrigation on yield and soil water balance of a maize crop (SAMAS TZEE), Nigerian. Aust. J. Basic Appl. Sci. 20, 357-367.

Klein Tank, A., Wijngaard, J., Können, G., Böhm, R., Demarée, G., Gocheva, A., Mileta, M., Pashiardis, S., Hejkrlik, L., Kern-Hansen, C., 2002. Daily dataset of 20th-century surface air temperature and precipitation series for the European Climate Assessment. Int. J. Climatol. 22, 1441-1453.

Martínez, Y., Albiac, J., 2006. Nitrate pollution control under soil heterogeneity. Land Use Policy 23, 521-532.

McMaster, G. Ii, J.A., Edmunds, D., Andales, A., Wagner, L., Fox, F., 2005. Multi-crop plant growth modeling for agricultural models and decision support systems. Proc. MODSIM 2005 Intl. Congress on Modelling and Simulation, pp. 2138-2144.

Mitchell, J., Singh, P., Wallender, W., Munk, D., Wroble, J., Horwath, W., Hogan, P., Roy, R., Hanson, B., 2012. No-tillage and high-residue practices reduce soil water evaporation. Calif. Agric. 66, 55-61.

Molden, D., Oweis, T., Steduto, P., Bindraban, P., Hanjra, M.A., Kijne, J., 2010. Improving agricultural water productivity: between optimism and caution. Agric. Water Manag. 97, 528-535.

Monteny, G.J., 2001. The EU Nitrates Directive: a European approach to combat water pollution from agriculture. Sci. World J. 1, 927-935.

Nagy, J., Rátonyi, T., 2013. Soil Cultivation and Land Use. University of Debrecen. last access: November 2016. http://www.tankonyvtar.hu/hu/tartalom/tamop412A/2011_ 0009_Nagy_Janos_Ratonyi_Tamas-Soil_Cultivation_and_Land_Use/ch05s05.html.

Parton, W.J., Ojima, D.S., Cole, C.V., Schimel, D.S., 1994. A general model for soil organic matter dynamics: sensitivity to litter chemistry, texture and management. Quantitative modeling of soil forming processes 147-167.

Playán, E., Mateos, L., 2006. Modernization and optimization of irrigation systems to increase water productivity. Agric. Water Manag. 80, 100-116.

Pradhan, P., Fischer, G., van Velthuizen, H., Reusser, D.E., Kropp, J.P., 2015. Closing yield gaps: how sustainable can we be? PLoS One 10, e0129487.

Robinson, S., 2002. New simulation output analysis techniques: a statistical process control approach for estimating the warm-up period. Proceedings of the 34th Conference on Winter Simulation: Exploring New Frontiers, pp. 439-446.

Saxton, K., Rawls, W.J., Romberger, J., Papendick, R., 1986. Estimating generalized soilwater characteristics from texture. Soil Sci. Soc. Am. J. 50, 1031-1036.

Schröder, J., Aarts, H., Van Middelkoop, J., Schils, R., Velthof, G., Fraters, B., Willems, W., 2007. Permissible manure and fertilizer use in dairy farming systems on sandy soils in The Netherlands to comply with the Nitrates Directive target. Eur. J. Agron. 27, 102-114.

Smith, M., 1993. CLIMWAT for CROPWAT. A Climatic Database for Irrigation Planning and Management. FAO.

Sommerfeldt, T., Chang, C., Entz, T., 1988. Long-term annual manure applications increase soil organic matter and nitrogen, and decrease carbon to nitrogen ratio. Soil Sci. Soc. Am. J. 52, 1668-1672.

Steduto, P., Hsiao, T.C., Fereres, E., Raes, D., 2012. Crop Yield Response to Water. Food and Agricultural Orgnization, Roma, Italy.

Sumner, M.E., 1999. Handbook of Soil Science. CRC press.

Townsend, T., Ramsden, S., Wilson, P., 2015. How do we cultivate in England? Tillage practices in crop production systems. Soil Use Manag. 32, 106-117.

Triplett, G., Dick, W.A., 2008. No-tillage crop production: a revolution in agriculture! Agron. J. 100, S-153-S-165.

Valero, J.D.J., Maturano, M., Ramírez, A.A., Martín-Benito, J.T., Álvarez, J.O., 2005. Growth and nitrogen use efficiency of irrigated maize in a semiarid region as affected by nitrogen fertilization. Span. J. Agric. Res. 3, 134-144. 
Van Grinsven, H., Ten Berge, H., Dalgaard, T., Fraters, B., Durand, P., Hart, A., Hofman, G. Jacobsen, B.H., Lalor, S.T., Lesschen, J., 2012. Management, regulation and environmental impacts of nitrogen fertilization in northwestern Europe under the Nitrates Directive: a benchmark study. Biogeosciences 9, 5143-5160.

Van Grinsven, H.J., Tiktak, A., Rougoor, C.W., 2016. Evaluation of the Dutch implementation of the nitrates directive, the water framework directive and the national emission ceilings directive. NJAS-Wageningen J. Life Sci. 78, 69-84.

Wang, X., Williams, J.R., Gassman, P.W., Baffaut, C., Izaurralde, R.C., Jeong, J., Kiniry, J.R., 2012. Epic and Apex: model use, calibration, and validation. T Asabe 55, 1447-1462. Williams, J.R., Izaurralde, R.C., 2006. The APEX model. Watershed Models, pp. 437-482.
Williams, J., Jones, C., Kiniry, J., Spanel, D.A., 1989. The EPIC crop growth model. Trans. ASAE 32, 497-0511.

Williams, J.R., Izaurralde, R.C., Steglich, E.M., 2008. Agricultural policy/environmental eXtender model: theoretical documentation version 0604. BREC Rep. 17.

Zhou, J.B., Wang, C.Y., Zhang, H., Dong, F., Zheng, X.F., Gale, W., Li, S.X., 2011. Effect of water saving management practices and nitrogen fertilizer rate on crop yield and water use efficiency in a winter wheat-summer maize cropping system. Field Crop Res. 122, 157-163. 